\title{
Empowerment of Small to Medium Enterprises using Franchise Takeover Model
}

\author{
Dewi Sulistianingsih ${ }^{1 *}$, Pujiono $^{1}$ and Rini Fidiyani ${ }^{1}$ \\ ${ }^{1}$ Faculty of Law, Semarang State University, Semarang, Indonesia
}

\begin{abstract}
Small to medium enterprises (SMEs) have really great potential as a national economic booster. However, SMEs encounter some obstacles and detentions. On the other hand, franchising is growing up to remote areas and overcoming the market of a product. It needs a special strategy required by the local and also central government to increase the capability of SMEs in realizing the national economic booster. This research aimed to evaluate the policies made by the local government in developing SMEs through franchise take over policy to improve SMEs as well as dealing with the obstacles, and to analyse the readiness of SMEs perpetrator in managing franchise business, especially from the legal perspective. This research is qualitative in nature. Qualitative methods are used in order to locate the hidden meanings from the research subjects. This research is using the Socio-Legal method. The result of this research is the local government's policy to give extra attention to SMEs with a new method that is franchise takeover model. The advantage and disadvantage of this model need to be analyses Small to medium enterprises (SMEs) have really great potential as the national economic booster.
\end{abstract}

\section{Introduction and literature review}

Small and medium-sized enterprises (SMEs) are of fundamental importance to many economies [1]. The sector of SMEs occupies in the economy very important place as the driving force of business, growth, innovation, and competitiveness. SMEs sector plays a decisive role in job creation and generally is a factor of social stability and economic development [2]. SMEs creates businesses, and businesses create jobs and income [3]. The specific characteristics that SMEs possess are that: (1) they are labor intensive enterprises, (2) they are available in many locations, especially in the rural areas, (3) they are more dependent on local raw materials, and (4) they are the main suppliers for the community's main necessity goods and services, especially those of low-income or poor community members [4]. The SMEs' characteristics are their potentials which can be developed into important assets for their developments.

Meanwhile, the government policies in the economic and monetary sectors also play a significant role in SMEs' development. The policies which significantly influence SMEs' developments are those related to rupiah currency exchange, fuel price increase, electricity

\footnotetext{
* Corresponding author: dewisulistianingsih21@gmail.com
} 
tariff increase, and labor's wage. Those monetary and economic policies negatively influence the development of SMEs since they still have poor management and low transfer of production technology. Moreover, the monopoly practices and unhealthy competition conducted by major enterprises in their business activities have created a customized market $[5]$.

The recent ability of the SMEs to understand the market's demands is not well-trained. They do not have yet a necessary ability to grasp accurately what the market wants. Besides, the SMEs still depend on the conventional method of marketing their products, which is mouth-to-mouth marketing. Most SMEs are not familiar with the use of social media applications or the internet as marketing tools [6].

On the other hand, modern chained stores like Alfamart dan Indomart grow and develop rapidly in many areas. Their emergence has indirectly opened up opportunities for the SMEs' entrepreneurs to utilize the stores to market their products.

The modern chained stores apply certain standards when marketing a product. The standardization of the products which are going to be sold in the stores is considered as the quality assurance to the consumers that the products available in their stores are highly qualified. The standardization from the stores gives an extra challenge as well as an obstacle for the SMEs' entrepreneurs.

The problems faced by the SMEs entrepreneurs in marketing their products in the modern chained stores need government's assistance in the form of affirmation policies. The policies have to be carried out by both the central and regional governments to support the marketing of SMEs' products, either by creating new markets or endorsing incentives to those who can export their products in the international market.

\subsection{The SME's Affirmation in Kulonprogo Regency of Jogjakarta}

Kulonprogo regency, like any other areas, has become one of the destination markets for modern chain stores. The emergence of the stores is the result of the economic and the community's demand development in the area. In order to accommodate the community's demand, on one hand, modern market or stores are mushrooming and the government is trying to develop SMEs on the other.

One of the affirmation efforts carried out by the government of Kulonprogo regency in developing and protecting the SMEs around the regency is by issuing Regional Regulation Number 11 of 2011 on the Protection and Empowerment of Traditional Markets and the Modern Store and Shopping Centre Restructuring. The regulation stipulates that modern chained and franchise stores shall be located at least 1000 (one thousand) meters away from the traditional market or else they will be shut down.

The regional regulation once sparked a polemic in the middle of the community since there are 18 (eighteen) modern chained or franchise stores, like Alfamart and Indomart in the regency which has to be shut down because they violate the regulation. In order to avoid the polemic from occurring in the community regarding with the implementation of the regional regulation number 11 of 2011, the government of Kulonprogo regency creates a policy not to extend the operational permission for modern chained or franchise stores whose permission is expired. Meanwhile, the government still let the stores whose permissions are valid to operate.

\subsection{Business Takeover of the Franchise Stores with ToMiRa Program}

Because there are modern chained (franchise) stores which have to be shut down since they violate the regional regulation number 11 of 2011, the Kulonprogo regent, Hasto Wardoyo, considers of issuing a new policy to seek alternative solutions for the modern chained 
(franchise) stores which are shut down to focus on the development of Kulonprogo regency. This action is also called: "Bela Beli Kulonprogo" (Let’s Empower Kulonprogo).

The solution taken by the regional government of Kulonprogo is expected to favor both the democratic economy and the businesspeople running modern chained (franchise) stores. The government issues a policy which is called "Toko Milik Rakyat (ToMiRa = Peoples' Stores) program. The program is a breakthrough in developing SMEs' businesses. It takes over the ownership of the modern chained (franchise) stores which are shut down based on the regional regulation number 11 of 2011. The takeover is carried out by a partnership between cooperatives and SMEs.

\section{The objective of the study}

The paper is written to analyze an SMEs' empowerment policy in Kulonprogo regency of Special District of Jogjakarta. The policy is carried out by taking over franchise businesses in accordance with the regional regulation number 11 of 2011 on the Protection and Empowerment of Traditional Markets and the Modern Store and Shopping Centre Restructuring.

\section{Methodology}

In collecting the materials, the researcher applied an interview method. The interview was carried out structurally following an interview guideline prepared by the researcher. The objective of using the interview guideline is to enable the researcher to collect information and data from the respondents. The respondents were chosen using a purposive random sampling technique. The collected data were then examined for their validity by using a triangulation technique. The data which had been examined for their validity afterward were analyzed using a qualitative data analysis.

\section{Discussions}

SMEs are significant in underlying country's economic growth, employment generation and accelerated industrialization [7]. In making a policy which aims to empower SMEs, Indonesia can learn from new industrial nations' experience like South Korea and China. Each country faces different challenges but also has many opportunities [8]. They apply an event distribution as the motor of their economic activity development. Policies need to be changed when facing a globalization era. Globalization - the trend toward a single, integrated, and interdependent global economy propelled by increases in international capital flows, international travel, the cross-border exchange of information and ideas, and trade in goods and services - has prompted franchisors to think of the world as one market and to examine common needs within and across societies [9]. The internationalization of SMEs can be expected to gain further momentum because the world economy is becoming increasingly integrated with continued declines in government-imposed barriers and continued advances in technology [10]. Globalization is a process of rapid capitalism development, which is marked with market globalization and production process [11].

Santos proposed 4 (four) concepts underlying or influencing a global management which is elaborated based on the tendency adhered to contemporary transglobal characteristics, which are globalized localism, which is confronted with localized globalism, and cosmopolitanism, which is confronted with common heritage of humankind [12]. Each of them has its own justification bases. The globalized localism is centered on the emphasis on how to globalize local values, while localized globalism is on the emphasis on how the global 
values can be localized or managed in accordance with the local values, interests, and needs. Meanwhile, the cosmopolitan and common heritage of humankind lies on how to be humans who become parts of global humanity concept and/or totally coordinated members of the world society.

Based on the concepts proposed by Santos, the policy of Kulonprogo regional government number 11 of 2011 is considered as a policy which attempts to implement globalized localism, since the regional government tries to globalize local products of the regency by means of the modern chained (franchise) stores. The policy of the regional government to globalize their local products is facilitated by the law. Law in the global era serves several functions as follows [13]: (1) Facility function. The law facilitates in achieving an order situation; (2) Repressive function. The law is used by the elite as a tool to achieve their goals; (3) Ideologic function. The law guarantees legitimation, hegemony, domination, liberty, and freedom achievements, etc.; (4) Reflective function. The law reflects communal desires in the community which forces it to act neutral.

By implementing the law functions, it is proven that there have been paradigm changes in the development of the economy which was growth-with-equity-centered to equity-forgrowth-centered. This paradigm change has been implemented in the implementation of the franchise business takeover carried out by the cooperatives and SMEs in Kulonprogo regency. A lot of policies have been carried out by the Government to empower SMEs in Indonesia [14] and one of them is the policy which is conducted by the Government in Kulonprogo Regency. The government as a regulator is very strategic in the process of making policy. Policies that can facilitate the process of developing and empowerment SMEs [15]. The government must be taking a good strategy for the empowerment of SMEs. So, empowerment is carried out to make SMEs a strong and independent business in a national economy. In the process of empowerment SMEs, its must involve the government, business, and society [16].

Franchising has been used as a tool for SMEs development in some newly industrialized and developing countries with reasonable success [17]. The franchise business model is considered to be a driver of employment and development of entrepreneurship and is determined by the method of successful business operations and an optimal number of employed in the franchise system. The franchisor has to develop its own sales team for development and support of the franchising network, aiming at maximizing profits, which ultimately increases the income and number of employees [18]. A franchise is a business model that has proven successful, that is why many entrepreneurs using this business model [19]. Business with a franchise system is a business for SMEs in Indonesia so that they can develop technology, packaging, service management, trademarks, etc.

The takeover of franchise businesses by the cooperatives and SMEs into Peoples' Stores (ToMiRa) in Kulonprogo regency is an act of redistribution of major businesspeople assets to that of SMEs. The asset redistribution shows that the government is in favor with the SMEs. The takeover of modern chained (franchise) stores which are carried out by the cooperatives and SMEs aims to create a joint venture among the stores, the cooperatives, and the SMEs. The cooperation is expected to benefit all parties involved in the takeover. In the takeover process, the modern chained (franchise) stores can still operate providing that they sell local products produced by the cooperatives and SMEs. This takeover is one of the affirmation actions carried out by the regional government to protect MSMEs from the unfriendly business competition.

So far, a lot of SMEs policies have been implemented in Indonesia. However, these policies have not been optimal. On the one hand, the government issued a policy to encourage SMEs but on the other hand, there were policies that obstructed the development of SMEs. different from the policies carried out in Kulonprogo. Kulonprogo carries out an "extraordinary" policy, giving SMEs a "new breath". Strategic planning in SMEs must be 
considered seriously by the executives $\{20\}$. This is what the Kulonprogo government have done. The government did that to empowering SMEs in Kulonprogo. The Empowerment of small and medium enterprises will be key in order to improve the survive possibility of the country. In moving the people's priority economy, the defense of government is absolute. Governments should provide material capital, intellectual and institutional [21].

The takeover of the modern chained (franchise) stores using ToMiRa model has given positive impacts for the cooperatives and SMEs located in Kulonprogo regency. The Head of Cooperatives and SMEs Office of Kulonprogo regency Sri Harmintari said that before the establishment of ToMiRa, the capacity of the cooperatives in retail management, system, and marketing was limited. After the establishment of ToMiRa, there was a significant change in the cooperative capacity, because of the brand combination of Alfamart and Indomart brands with that of Peoples' Stores (ToMiRa). Besides, the store and the cooperative employees are not charged with goodwill and royalty fees. Hence, this will not burden the cooperative's financial condition. The stores are also required to sell local Kulonprogo products which have been standardized with PIRT (Home Industry Food Products), HKI (Intellectual Property Rights), MUI (Indonesian Council of Religious Scholars) Halal Certification, etc.

With the establishment of ToMiRa, there are 20 (twenty) local Kulonprogo products which can be marketed in the stores. They are: (1) "Mina Rasa" crispy fish, (2) Eel chips, (3) "Nyoss" chili abon, (4) Dragon fruit sticks, (5) "Rohana" banana chips, (6) "Sari Nila" crystal sugar, (7) Boxed "Sari Nila" ginger. (8) Canned "Sari Nila" ginger, (10) Gotu Kola chips, (11) "Menoreh" crackers, (12) Rengginang, (13) Oyster mushrooms, (14) "Kali Bawang" slondok, (15) "Benguk" soybean sauce, (16) "Garut" emping, (17) "Menoreh" mocha coffee, (18) Black tea powder, (19) Ginger coffee, (20) Mocha coffee which have been previously sold in the modern chained (franchise) stores.

There are some locally produced products by the government of Kulonprogo. For example, the local water company (PDAM) of Kulonprogo produces bottled mineral water which is branded with "Airku". There are also rice products by a cooperation of groups of farmers in Kulonprogo. There are also local SMEs' products like rengginang, ginger chips, wingko, "benguk" tempeh. Approximately, there are 60 different local products in total. It is expected that 50 percent of the items sold in ToMiRa are local products. The products which are sold in ToMiRa have passed several tight selections processes, both for their qualities and packaging.

\section{Conclusions}

The modern chained (franchise) stores takeover carried out by the cooperatives and SMEs is an act of affirmation by the government of Kulonprogo regency. This act aims to protect and develop SMEs from the global competition by utilizing the functions of the existing applicable law.

Takeover in modern shops with franchise mechanism, conducted by the government of Kulonprogo Regency through the regional regulation number 11 of 2011. This method is able to empower SMEs, we can see there is a lot of products in modern franchised stores. This takeover method also utilizes the legal function in the globalization era, especially the legal functions which can harmonize between globalized localism and localized globalism. 


\section{References}

1. J. A. Peprah \& A. O. Menjah, EJBSS, 4, 26 (2016).

2. S. Karel, P. Adam, P. Radomir, JC, 5, 58 (2013)

3. B. Anad, PSBS, 195, 1006 (2015)

4. T. T.H. Tambunan, PP, 15, (2013)

5. A. T. Prasetiantono, Democratic Economy and Free Market, in Kiswondo, et.al (editor), The New Economic Politics in Indonesia, (Pustaka Pelajar, Yogyakarta, 2000)

6. LPPI, Bank of Indonesia, The Business Profile of Micro, Small, and Medium Enterprises, Jakarta: LPPI and Bank Indonesia, 2015)

7. K. Ahmed, T.A. Chawdhury, IJBM, 4. 131 (2009)

8. Z.G. Antonios, IJBHT, 5, 34 (2015)

9. I. Alon, JM, 24, 156 (2004)

10. J.W. Lu and P.W. Beamish, SMJ, 22, 265 (2001)

11. D. Sulistianingsih, Pujiono, A. Busro, JBEP, 4, 44 (2017)

12. B. D. S. Santos, Toward A New Common Sense: Law, Science and Politics in the Paradigmatic Transition, (Routledge, New York, 1995)

13. M. Fuady, Grand Theories in Legal Studies, (Jakarta: Kencana, 2013)

14. D. Wulandari \& H. Maeilani, JEBP, 4, 103 (2013)

15. S. Abraham, IP, 4, 1051 (2016)

16. Subarsono, Y. Barlianto, \& Sulfiani, JE, 5, 17 (2016)

17. N. Sanghavi, MRN, 21, 37 (1998)

18. M. Alpeza, A. Erceg, S.O. Peterka, RIC, 1, 10 (2015)

19. P. Sulistyaningsih, Heniyatun, H. Hendrawati, JHN, 8, 138 (2017)

20. A.A. Castro, V.V. Ortiz, EA, 12, 32 (2016)

21. Faizal M. \& S.A.S.P. Muljono, IJHSS, 4, (2014) 